\title{
BUDAYA TEKTONIKA WOLOGAI ENDE, NUSA TENGGARA TIMUR \\ Sebuah Seni Berkonstruksi Rumah Adat Desa Wologai Tengah, Kecamatan Detusoko, Warisan Leluhur Wawo - Ata Lio di Bawah Kaki Gunung Lepembusu
}

\author{
Reginaldo Ch. Lake \\ Prodi Arsitektur, Universitas Katolik Widya Mandira, Kupang, Timor, NTT \\ egilake@yahoo.com
}

\begin{abstract}
Abstrak
Ternyata budaya tektonika di dunia arsitektur Nusantara-Indonesia ini belum banyak dikemukakan. Padahal budaya tektonika melekat dalam pengertian kata arsitektur itu sendiri, yakni dari kata archi (master atau chief) dan tekton (kata benda), yang berarti tukang kayu (carpenter) atau builder. Dengan demikian, kata tektonika terkait dalam pemahaman cara membangun dan terkait seni berkonstruksi. Hal ini sangat menarik jika ditelusuri dalam budaya masyarakat Nusantara kita, karena masih dianggap tabu untuk diungkapkan akibat budaya lisan yang diwariskan secara turun-temurun.

Menyadari pemikiran di atas, pada kesempatan ini, penelitian akan terfokus pada proses pembangunan (budaya tektonika) arsitektur vernakular, yakni pada sebuah desa adat Wologai di Flores, Nusa Tenggara Timur. Objek studi ini dipilih karena memiliki karakter unik dalam pengungkapan budaya tektonika (seni berkonstruksi) arsitektur vernakular; selain itu desa adat Wologai merupakan salah desa bersejarah di wilayah Ende, Flores, Nusa Tenggara Timur. Keaslian desa ini masih terjaga karena wujud budaya, aktifitas dan norma-norma budaya masih diwariskan sampai saat ini.

Penelitian ini dibagi menjadi tiga bagian: bagian pertama, studi lapangan yakni dokumentasi proses pembangunan rumah adat dan interview. Bagian kedua, studi literatur yang relevan mengenai budaya tektonika. Bagian terakhir, adalah analisis dan rumusan budaya tektonika masyarakat adat Wologai.
\end{abstract}

Kata kunci: budaya tektonika, Wologai.

\begin{abstract}
Title: Culture of Tectonics Wologai - Ende, a Traditional House Constructed of Art Central Wologai Village, District Detusoko, Ancestral Heritage, Waeo - Ata Lio Under the Foothills of Lepembusu
\end{abstract}

As a counterbalance to globalization in the field of architecture, an in-depth understanding of local architecture had been seen as an opportunity for a region to play an active role in the global era. One way to develop an understanding of local architecture is through the art of construction, or widely known as tectonics. The word architecture itself was known to derive from the word archi, which means master and tekton, which means woodworker (carpenter) or builder. Thus, the study of tectonics was important to understand how architects express their ideas through an integrated architectural - structural system. Unfortunately, profound research into this field has rarely been conducted so far.

This study aims to an understanding of architectural tectonics in Wologai, Flores, Nusa Tenggara Timur. As one of the oldest village in Flores, the indigenuous people of Wologai had been known for surviving the pressures of the developing world whilst maintaining their unique culture that were reflected in their vernacular buildings.

This study consists of the following steps: Firstly, to record how local builders built their architecture through observation and interviews. Secondly, to develop an understanding about 
architectural tectonics based on related literature. The last step was to analyse and formulate architectural tectonics of Wologai vernacular architecture.

Keywords: culture of tectonics, Wologai

\section{Latar Belakang}

Bahasan tektonika sangat erat dengan dunia arsitektur pada masa lampau seperti yang sudah dikenal sejak zaman arsitektur Yunani dan Romawi yang diungkapkan dalam pengertian istilah "arsitektur" itu sendiri. Pembendaharaan kata "arsitektur" berasal dari kata bahasa Yunani, "architekton", yang berarti master builder atau ahli membangun. Secara etimologi, kata "archi" berarti chief of master dan "tekton" (kata benda) yang berarti tukang atau pembangun (builder atau carpenter).

Sejalan dengan perkembangan langgam-langgam atau istilah gaya arsitektur, maka pendekatan arti kata arsitektur menjadi luas dan berkembang, mulai dikaitkan dengan ilmu seni merancang, ilmu perhitungan konstruksi bangunan hingga ilmu dan praktik mendesain. Bahkan pengertian arsitektur berkembang menjadi istilah "sebuah metode atau suatu cara dimana komponen komputer atau sistem komputer diorganisasikan dan diintegrasikan" (Meriam Webster, 2003).

Fenomena di atas menjadikan pengertian arsitektur yang pada awalnya dipahami sebagai "ilmu merancang bangunan" kini berkembang menjadi sebuah pemahaman seni mendesain bangunan dan meluas menjadi bagian dari ide merencanakan kota. Dari ragam definisi tersebut, telaah ini akan menelusuri kata tektonika dalam pengertian "tekton" yang berarti tukang atau pembangun. Jika dikaitkan dengan budaya tektonika maka lebih tepat disejajarkan dalam budaya vernakular yang tentunya kata tukang dalam budaya vernakular tidak terlepas dari pengetahuan, pengalaman dan normanorma yang diterapkan dalam masyarakat (komunitas) tersebut dari satu generasi ke generasi yang lainnya. Pemahaman singkat tersebut dipertegas oleh Oliver (2003) yang mengatakan bahwa dalam tektonika sebuah bangunan masyarakat vernakular, terdapat "the inherited knowledge of the natural environment of climate, topography, season variation, natural hazard, sustainability of site.....".

Hal spesifik dalam Oliver (2006), dia menyebut pengetahuan tukang atau pembangun dalam masyarakat vernakular sebagai "know-how which related to method or technique" serta "the knowledge of natural, material resource, and how they may be utilized, nurtured or replaced...."

Dari uraian inilah pengertian tektonika menjadi spesifik. Budaya tektonika yang dikaitkan dengan budaya vernakular adalah cara membangun oleh komunitas (masyarakat) vernakular yang diwariskan dari satu generasi ke generasi lainnya. Dalam proses tektonika budaya vernakular ini terdapat pengertian seni berkonstruksi, penggunaan material, masyarakat pemeran tektonika, sekaligus normanorma atau aturan budaya tektonika dalam masyarakat tersebut, yang terlihat jelas upacara-upacara mendirikan bangunan vernakular, 
simbol-simbol serta estetika yang digunakan dan status sosial yang diwujudkan dalam ragam hias bangunan vernakular.

Sudah saatnya budaya tektonika ini perlu dikaji sebagai sebuah tuntutan proses pembelajaran arsitektur lokal kita. Artinya, kearifan lokal cenderung terus-menerus diabaikan bahkan kurangnya pemahaman dan rasa cinta pada warisan budaya Nusantara. Tentu saja budaya tektonika ini menjadi arsitektur sumber yang dapat diterapkan dalam kekinian arsitektur kita. Pentingnya budaya tektonika ini maka budaya tektonika yang akan ditelaah secara spesifik dalam budaya vernakular pada kesempatan ini adalah budaya tektonika desa adat Wologai Tengah, di Kecamatan Detusoko, Ende, Provinsi Nusa Tenggara Timur. Desa adat Wologai dipilih sebagai objek studi karena tiga hal. Pertama, keunikan permukiman vernakular desa Wologai sangat beragam baik itu tata suku masyarakat adat yang membentuk tata ruang, serta masih lestari hingga saat ini. Kedua, Pemerintah telah menetapkan desa adat Wologai sebagai desa bersejarah karena sudah berusia lebih dari 50 tahun. Dan ketiga, ada hubungan (keterkaitan) spesifik antara budaya tektonika dengan simbolsimbol status sosial serta norma-norma yang berlaku dalam budaya vernakular yang unik tersebut. Spirit ini menarik untuk diangkat sebagai objek studi yang dapat mengungkap terbentuknya konsep budaya tektonika (seni berkonstruksi) arsitektur vernakular.

Hal ini sangat penting, sebab pemahaman tentang hakikat budaya tektonika pada arsitektur vernakular merupakan dasar dan pijakan awal bagi pelestarian jiwa arsitekturnya, sebagai bagian dalam pengembangan ilmu pengetahuan tentang kearifan lokal arsitektur permukiman vernakular di Nusantara.

\section{Rumusan Permasalahan}

Telaah ini berupaya mengungkapkan budaya tektonika Wologai sebagai bagian dari upaya memahami dan melestarikan arsitektur lokal, khususnya berfokus pada identifikasi proses pembangunan arsitektur vernakular Wologai; mulai dari:

1. Tahapan pembangunan;

2. Peralatan dan material yang digunakan;

3. Struktur pelaku dalam pembangunan, serta

4. Norma-norma yang ada dalam proses pembangunan dan simbolsimbol budaya yang dipakai dalam wujud arsitektur vernakular Wologai.

\section{Tujuan Penelitian}

Tujuan penelitian ini adalah:

1. Mengungkapkan semua elemen pembentuk konstruksi bangunan arsitektur vernakular Wologai.

2. Identifikasi budaya tektonika dari masyarakat Wologai.

\section{Manfaat Penelitian}

Budaya tektonika dalam dunia arsitektur belum banyak ditelaah. Telaah budaya tektonika suatu masyarakat vernakular dapat memperkaya khazanah pengetahuan arsitektur lokal sebagai sumber arsitektur kiwari Nusantara, khususnya pemahaman material bangunan sesuai iklim setempat, hubungan antar bentuk, struktur dan konstruksi arsitektur lokal, pembentukan ruang dan makna yang terkandung dalam seni berkonstruksi arsitektur vernakular Wologai. 


\section{Metodologi dan Pembahasan}

Metode yang dipakai dalam penelitian ini adalah empirical research method dengan analisa kualitatif bersifat deskriptif. Metode ini dipilih karena penelitian ini bergantung pada data dan informasi objek studi yang terkumpul. Pendekatan kualitatif, karena penelitian ini akan membahas mengenai "kualitas" (hakikat, esensi) budaya tektonika Wologai.

Pembahasan dalam tulisan ini dibagi menjadi tiga bagian:

1. Bagian pertama, studi di lapangan terdiri dari 2 bagian:

a. Dokumentasi proses pembangunan $\mathrm{Sa} O \mathrm{O}$ di desa adat Wologai;

b. Interview dengan para mosalaki (tua adat) tentang tradisi membangun $\mathrm{Sa}$ 'O di Wologai.

2. Bagian kedua, studi literatur mengenai budaya tektonika dari buku teori Barat yang berfungsi sebagai teori pembanding budaya tektonika objek studi.

3. Bagian ketiga, analisis dan rumusan budaya tektonika masyarakat vernakular Wologai yang dikaji dari 3 hal utama, yakni: susunan (pranata) sosial yang terlibat, pengetahuan membangun, makna dan nilai-nilai dalam budaya vernakular Wologai serta material yang dipakai dalam proses membangun.

\section{Tektonika dalam Arsitektur}

Istilah tektonik berasal dari bahasa Yunani yang merujuk pada pelaksana pembangunan atau tukang kayu. Dari pemikiran Karl Freidrich Schinkel (1781-1841), tektonika merupakan ekspresi arsitektural yang muncul sebagai konsekuensi prinsip mekanika yang diterapkan dalam bangunan Tektonik merupakan ekspresi yang terungkap akibat penerapan prinsip statika yang bekerja pada wujud konstruksi yang ada, sehingga selain ekspresi yang terungkap itu, terdapat pula pemahaman dalam lingkup struktur dan konstruksinya.

Ping-Gao (1999) mengemukakan dua pernyataan tentang tektonika: pertama, berkenaan dengan terciptanya keruangan akibat hubungan dan kesesuaian antara material, sambungan, detail dan struktur ${ }^{5}$. Kedua, berkenaan dengan seni dan kreasi bentuk yang tidak hanya bermakna sebagai tempat berlindung dan berteduh, namun pengetahuan yang menghadirkan suatu konstruksi.

Semper lebih menegaskan klasifikasi bangunan (arsitektur) dengan 2 (dua) prosedur yang mendasari proses perakitannya, yakni (pertama) tektonika yang merupakan rangka ringan yang terdiri dari komponen linier membentuk matrik spasial; dan (kedua) tahapan stereotomik yang berupa bagian dasar dimana massa dan volume ruang terbentuk dari elemenelemen berat.

Dari pernyataan-pernyataan di atas, tektonika dapat dipahami sebagai wujud keterkaitan antara material, konstruksi, bentuk dan ekspresi pada obyek arsitektur. Dengan kata lain, tektonika dipahami sebagai piranti dasar untuk menghasilkan ekspresi arsitektural (dampak rangkaian elemen konstruksi yang timbul) dan meletakkan dasar pemahaman tersebut sebagai upaya untuk mengeksplorasi bentuk arsitektur.

\footnotetext{
${ }^{5}$ Teknologi dan metode membangun demi terciptanya keharmonisan struktur dan keruang-an, yaitu kelekatan arsitekturnya dengan konteks tapak yang meng-interaksikan antara, manusia, alam dan budaya.
} 
Secara etimologi, istilah tektonika muncul dari istilah arsitektonik atau architectonic, sedangkan tektonika yang diungkapkan oleh Frampton (1995) yang menyebutkan bahwa tektonika berasal dari kata tekton dan sering ditulis sebagai kata tektonamai dalam bahasa Yunani yang secara harafiah berarti pertukangan kayu atau pembangun.

Dalam bahasa Sansekerta, istilah ini dapat disamakan dengan kata taksan yang juga berarti seni pertukangan kayu yang menggunakan kapak. Istilah yang sama juga ditemukan dalam puisi Vedic yang juga berarti pertukangan kayu, kemudian dalam Homer, istilah ini diartikan sebagai seni dari konstruksi secara umum.

Dengan perjalanan waktu pengertian kata tektonika pada konstruksi cenderung membuat karya seni tergantung pada benar atau tidaknya penerapan tingkatan kegunaan nilai seninya. Kemudian Adolf Heinrich Borbein pada tahun 1982 (Frampton, 1995) pada studi Philologinya yang mengatakan bahwa tektonika menjadi seni pertemuan atau sambungan; seni dalam hal ini ditekankan pada tekne, sehingga tektonika ternyata bukan hanya bagian dari bangunan tetapi juga obyek atau sebagai karya seni pada arti yang lebih sempit.

Namun sebagai suatu karya seni, arsitek seharusnya memberi perhatian lebih pada kreatifitas pengolahan bentuk elemen-elemen suatu sistem struktur yang diterapkan. Begitu pula akan pengenalan yang baik dan benar terhadap properti material bangunan, sehingga arsitek dapat memilih secara tepat material yang hendak dipakai, sampai kepada memutuskan metoda kosntruksi yang sesuai. Di sinilah arsitek membicarakan (mengetengah- kan) tektoni-ka untuk membuat karya arsitektur menjadi lebih kreatif dan kaya akan makna.

Tektonika merupakan artikulasi penyaluran beban pada elemen-elemen struktur. Pengolahan bentuk secara inovatif hingga menghasilkan potensi ekspresi bentuk arsitektural secara keseluruhan maupun ekspresi seni pada detail-detail sambungan konstruksi yang digunakan. Bentuk-bentuk yang dihasilkan merupakan bentuk-bentuk artistik yang mempunyai makna dan/atau nilai seni, bukan hanya bentuk yang abstrak atau sekadar figuratif saja, melainkan bahkan mampu pula mengekspresikan hal-hal simbolikfilosofis suatu bangunan.

Aspek struktur dan konstruksi merupakan aspek teknik yang mempunyai aspek simbolik yang representatif, dimana perwujudan bentuk dicapai dengan material yang memenuhi persyaratan struktur, seperti "stabil" (bisa berdiri) dan "kuat" (mampu menahan gaya-gaya yang bekerja).

Sedang pada aspek kreatifitas, pengolahan bentuk elemen struktur harus disertai dengan pengenalan yang baik dan benar pada properti material bangunan, sehingga aspek tektonika dalam karya arsitektur menjadi lebih kreatif dan kaya makna untuk mencapai keseimbangan bentukan (arsitektur).

Tektonika berperan sebagai mekanisme penyaluran beban dari gaya-gaya yang bekerja pada elemen-elemen struktur dengan pengolahan bentuk yang menghasilkan potensi ekspresi bentuk yang mempunyai nilai seni dan mengekspresikan simbolik filosofis dari bangunan. Pemilihan struktur 
bangunan juga mencerminkan fungsi di dalamnya.

Pada bangunan candi yang dibuat dengan struktur berat dari gaya-gaya yang bekerja pada elemen-elemen struktur dengan pengolahan bentuk yang menghasilkan potensi ekspresi bentuk yang mempunyai nilai seni dan mengekspresikan simbolik filosofis dari bangunan. Bangunan pendopo pada hunian tradisional dicerminkan dengan struktur rangka yang ringan dalam menerima tamu. Bangunan ibadah yang menuntut ekspresi bentuk yang agung dan sakral yang berfungsi untuk memunculkan alternatif pemilihan struktur, seperti bentuk gothic pada gereja, bentuk kubah pada masjid.

Aspek tektonika pada bangunan (arsitektur) berlanjut pada penyelesaian elemen-elemen struktur, seperti pada kolom-kolom, dinding-dinding, balokbalok plat lantai aap, serta detil-detil bangunan. Sehingga akan dapat dihasilkan suatu bentuk-bentuk tektonika yang baik, yang disertai kepekaan terhadap material dan inovasi struktur serta ekspresi bangunan.

Merancang struktur merupakan tindakan menempatkan unsur-unsur pokok dan merumuskan hubungan timbal-baliknya untuk menciptakan karakter yang diinginkan pada entitas struktur sebagai resultannya.

\section{Budaya Tektonika Wologai}

Pada awal pembahasan di atas, telah disebutkan bahwa penelusuran budaya tektonika Wologai akan dikaitkan dengan sistem sosial masyarakat adat tersebut. Hal ini sangat layak karena usia desa adat Wologai mencapai generasi ke 16 yakni lebih dari seratus tahun. Desa ini juga sekaligus merupakan salah satu desa tertua di daerah Ende, Flores Tengah. Penegas status tersebut dikemukakan oleh Dr. Joseph Glimka, pakar Antropologi Ragawi, yang melakukan studi mengenai manusia NTT. Ata Lio di Flores Tengah merupakan penduduk Flores tertua, karena mereka mendiami bagian paling tengah pulau Flores. Pemahaman wilayah tersebut dipengaruhi oleh otonomi pemekaran wilayah Flores yakni daerah pemekaran mengarah pada wilayah paling luar yakni bagian Timor dan Barat sehingga keberadaan sebuah wilayah bagian tengah dianggap wilayah paling tua.

\section{Struktur Masyarakat Wologai}

Tanah adat Wologai merupakan suatu kesatuan wilayah hukum adat yang berpusat pada Keda, Tubu Musu Kanga, sebagai inti tersakral dalam struktur adat Wologai

Menurut penuturan masyarakat kesatuan struktur adat Wologai, dilihat dari kehidupan sehari-harinya dibagi dalam 3 (tiga) bagian besar, yakni: Mosalaki, Ine ria fai ngg'ae dan Ana kalo fai walu.

\section{Mosalaki}

Mosalaki berari dewan penguasa (pemegang kekuasaan adat). Dewan ini adalah himpunan dari Atalaki tanah Wologai yang bertanggung jawab atas keutuhan serta kesejahteraan seluruh warga adat Wologai.

Di desa adat Wologai terdapat 38 orang mosalaki, yang kesemuanya adalah kaum laki-laki. Setiap rumah adat $\left(\mathrm{Sa}{ }^{\prime} \mathrm{O}\right)$ mempunyai mosalaki-nya sendiri. Jadi, ke-38 mosalaki tersebut boleh dinamai sesuai dengan namanama $\mathrm{Sa} O$.

\section{Ine ria fai ngga'e}

Disebut sebagai nyonya besar. Bertugas melaksanakan seremonial 
dalam rumah adat, seperti "rase pare". $S$ ' re are tana nasu uta watu, dan lainnya. Sebutan lain dari ine ria fai $n g g a$ ' $e$ di beberapa rumah adat lainnya adalah "ata ine" (mama).

\section{Ana kalo fai walu}

Sebutan bagi masyarakat secara umum, yakni anak dari ine ria fai ngga' $e$ atau ata ine dan para mosalaki.

Menurut sistem adat Lio, pemangku adat Lio terdiri atas beberapa klasifikasi gelar kebangsawan, yakni: mosalaki, boge, hage dan ria bewa. Dari semua sesepuh adat ini tentu mempunyai tugas dan wewenang masing-masing.

\section{Proses Pembangunan Sa' O (Rumah} Adat Wologai - Nua Pu' U)

Pembangunan $\mathrm{Sa}^{\prime} \mathrm{O}$ dilakukan beberapa tahap dan disertai upacaraupacara adat. Proses pembangunan rumah adat ini memakan waktu panjang, terutama tahap persiapannya yang (hampir) berbulan-bulan lamanya. Mula-mula diadakan tebo bou lo' $o$, yakni musyawarah pembangunan $s a$ ' $O ; \quad$ selanjutnya tahapan-tahapan sebelum proses pembangunan $s a^{\prime} O$, yakni:

1. Pemilik $s a^{\prime} O$ yang akan dibangun melakukan peramalan tentang lancar atau tidak lancarnya pembangunan $s a^{\prime} O$.

a. So bhoku au: proses ini adalah peramalan yang dilakukan oleh pemilik $s a^{\prime} O$ yang akan dibangun. Peramalan ini dilakukan untuk mengetahui apakah proses pembangunan $s a^{\prime} O$ akan lancar-lancar saja, atau justru penuh dengan tantangan. Proses ini dilakukan dengan cara membakar sebatang bambu, dan tentu saja disertai doa-doa khusus. Bila bambu yang dibakar pecah atau retak secara lurus, artinya proses pembangunan $s a^{\prime} O$ akan berjalan dengan lancar. Sebaliknya, bila pecah atau retakan bambu tidak lurus, artinya proses pembangunan $s a$ 'O nantinya akan menuai banyak tantangan dan rintangan.

b. Bui feo: proses ini adalah proses peramalan kedua setelah so bhoka au yang dilakukan oleh pemilik $s a$ 'O yang akan dibangun. Tujuannya pun sama dengan so bhoka au, yaitu untuk mengetahui lancar atau tidaknya pembangunan $s a^{\prime} O$. Proses ini dilakukan dengan membakar kemiri, dan tentu saja dengan doa-doa khusus pula. Bila nyala api yang dihasilkan oleh kemiri tegak ke atas, artinya proses pembangunan nantinya akan lancar. Namun, sebaliknya bila api yang dihasilkan oleh kemiri tidak tegak ke atas maka proses pembangunan nantinya akan menuai banyak tantangan dan rintangan.

Seandainya salah satu proses gagal (hasilnya tidak sesuai dengan harapan), maka pemilik $s a$ 'O yang akan dibangun akan mengurungkan niatnya untuk sementara waktu, dan tidak boleh melaksanakan proses berikutnya.

2. Bila kedua proses peramalan di atas berhasil, proses berikutnya adalah naka wishu. Naka wishu artinya sebatang kayu yang harus tersedia sebelum proses pembangunan $s a^{\prime} O$ berlangsung. Kayu tersebut disebut sebagai 
"kayu keramat yang dirahasiakan oleh pemilik $s a^{\prime} O{ }^{\prime}$ '. Pemilik $s a$ 'O mengambil wishu di hutan tertentu tanpa diketahui oelh orang lain (yang bukan pemilik $s a^{\prime} O$ tersebut). Dikatakan "mencuri wishu" karena pengambilan wishu dilakukan pada malam hari dengan diam-diam, dan pada saat dimana orang lain tertidur pulas. Secara fisik, ukuran wishu ini boleh jadi kecil dan nantinya boleh dipasang pada bagian struktur sa'O. Meskipun demikian, wishu harus menjadi yang pertama diadakan.

Material dasar yang digunakan hampir sepenuhnya didapat dari alam setempat. Material-material tersebut harus melalui upacara adat. Hal ini membuktikan bahwa pengetahuan masyarakat adat Wologai akan pelestarian alam sangat baik, sehingga upacaraupacara adat saat pengambilan material di hutan merupakan suatu bentuk penghargaan terhadap alam lingkungan Lepembusu-Wologai.

3. Wishu tersebut didiamkan selama 3 (tiga) hari, dan ditempatkan di atas (di sekitar) tapak tempat $s a^{\prime} O$ didirikan. Setelah 3 (tiga) hari tersebut, kemudian dilakukan pengumpulan material: batu, kayu, alang-alang, ijuk dan lain sebagainya.

4. Setelah material terkumpul, pemilik sa'O yang akan dibangun menghubungi tukang yang ahli dalam pembangunan $s a^{\prime} O$, disebut ata rawi. Selain ata rawi, pemilik $s a^{\prime} O$ juga menghubungi ahli ukir (ata nggesu). Sesuai tradisi, bayaran untuk ata rawi dan/atau ata nggesu adalah seliwut emas dan seekor binatang, yang dalam bahasa setempat disebut seliwu seeko. Proses ini boleh tawar menawar (bernegosiasi).

5. Setelah proses di atas, wиnu koli (pemilik) hanya menunggu hingga proses pembangunan selesai. Dalam proses pembangunan tersebut ata rawi dan ata nggesu senantiasa berkonsultasi dengan wunu koli, misalnya tentang ukuran $s a^{\prime} O$ dan ukiran yang akan disematkan pada $s a^{\prime} O$.

\section{Re-Konstruksi $\boldsymbol{S a} \boldsymbol{a}^{\prime} \boldsymbol{O}$}

a. Menggali Tanah

Pada dasarnya rumah adat $\left(s a^{\prime} O\right)$ di kampung adat Wologai - Nua Pu' U ini tidak menggunakan pondasi jalur sebagai penyangga bangunan, namun menggunakan material batu sebagai tiang-tiang (leke). Dalam hal ini leke sebagai penopang utama untuk menopang ruang-ruang di atasnya.

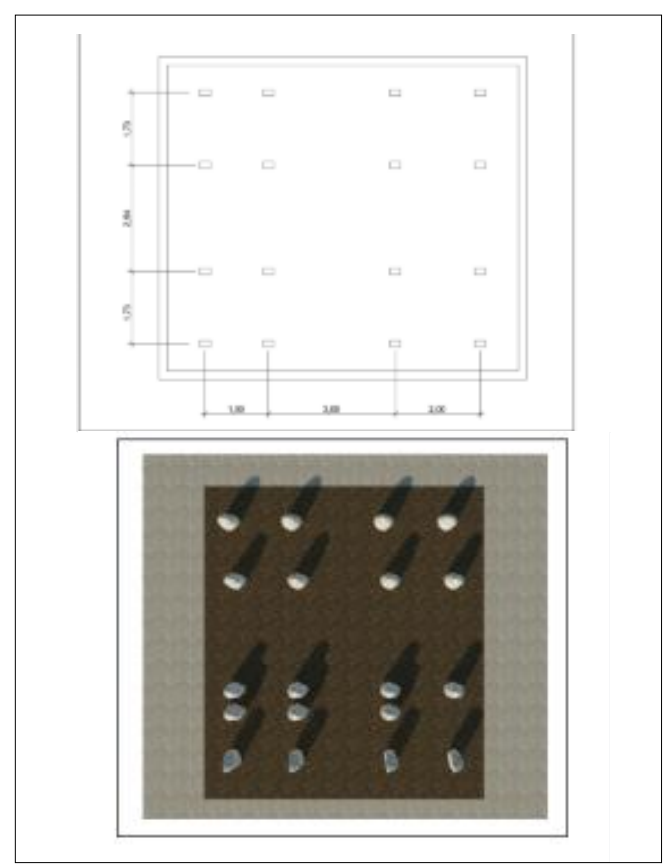

Gambar 1. Denah perletakan tiang yang akan digali

Sumber: Dokumentasi Pusat Studi Vernakular Unwira, trimatra oleh Egi, 2012 
Mulanya tanah yang sebelumnya sudah ditandai dengan patok, digali dengan kedalaman yang sesuai dengan leke. Untuk watu leke, kedalaman diukur dengan menggunakan lengan sampai telinga menyentuh permukaan tanah (oleh pemilik rumah adat). Lubang kemudian ditutup dengan tanah hasil galian dan dipadatkan untuk mencegah guncangan.

\section{b. Meletakkan Watu Leke}

Watu leke (umpak batu) diletakkan di dalam lubang yang telah digali, dengan alas berupa batu yang memiliki permukaan datar (batu pelat) agar tidak terjadi penurunan tanah saat musim hujan. Ukuran diameter tiang-tiang batu ini (watu leke) berkisar antara 20$30 \mathrm{~cm}$, dengan jenis batu yang kuat dan mampu menahan beban bangunan secara baik. Fungsinya adalah sebagai penopang kolom bangunan (sejenis umpak) untuk menanggung beban lantai dasar. Penggunaan batu sebagai penyangga bangunan secara efektif dapat meminimalisir kerusakan dini material bangunan oleh gangguan rayap dan lain sebagainya.

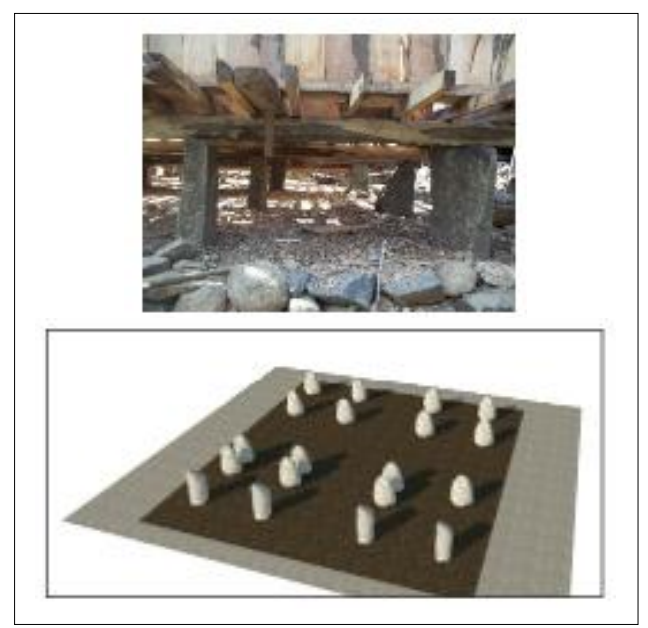

Gambar 2. Posisi meletakkan watu leke

Sumber: Dokumentasi Pusat Studi Vernakular Unwira, trimatra oleh Egi, 2012 c. Meletakkan Tenga untuk Lewu

Di atas barisan leke melintang tenga (balok induk). Selain sebagai balok penguat tiang-tiang dan penopang serta balok-balok melintang lainnya membujur berlawanan dengan jarum jam. Semua ujungnya di sebelah kanan. Bahan yang digunakan untuk bagian ini adalah kayu tanpa menggunakan sambungan apa pun. Dengan meletakkan tenga ini, maka terbentuk lewu (kolong). Lewu adalah ruang untuk hewan peliharaan seperti anjing, ayam dan babi. Ketinggian lewu (kolong) dari dasar tanah ke leke adalah $60-75 \mathrm{~cm}$.

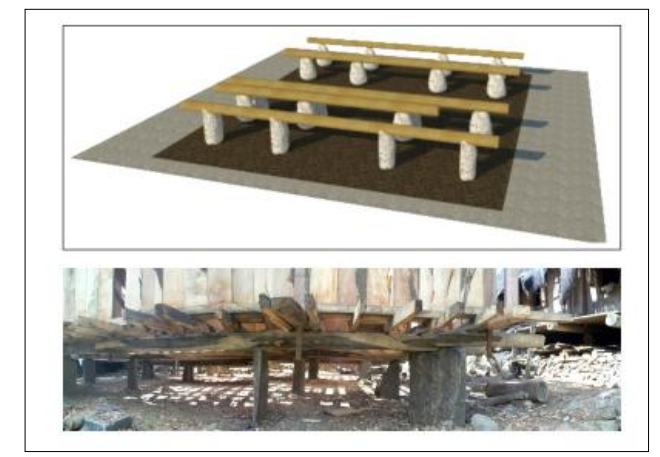

Gambar 3. Posisi meletakkan tenga untuk lewu

Sumber: Dokumentasi Pusat Studi Vernakular Unwira, trimatra oleh Egi, 2012

d. Meletakkan Lando untuk Dalo Lando berfungsi sebagai balok untuk dalo (lantai). Lando, yakni balok gelagar lantai diletakkan melintang dari tenga (balok induk) untuk menopang papan-papan lantai. Jumlah lando utama adalah 4 (empat) batang dan lando pendukung berjumlah 17 (tujuh belas) batang. Perlu diperhatikan bahwa cara masyarakat Wologai mengukur jarak antar lando adalah dengan jengkal tangan, yakni 1 (satu) jengkal. 

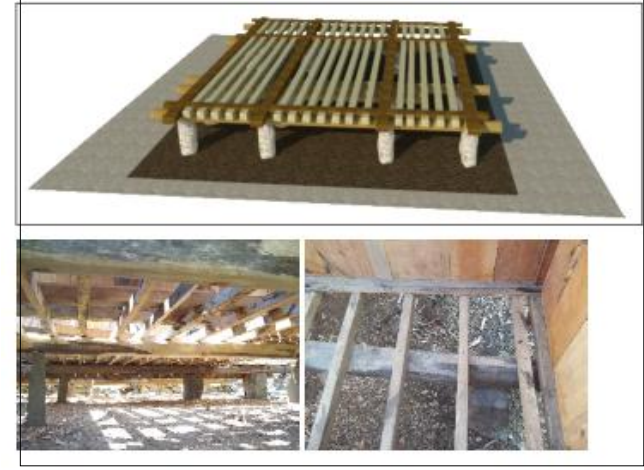

Gambar 4. Posisi meletakkan lando untuk dalo

Sumber: Dokumentasi Pusat Studi Vernakular Unwira, trimatra oleh Egi, 2012

e. Meletakkan Wisu (Tiang-tiang Kolom)

Perletakan wisu (kolom) dilaksanakan setelah lando-lando ditempatkan sesuai posisi. Pemasangan wisu adalah awal terbentuknya ruang-ruang dalam $s a^{\prime} O$. Wisu ini adalah kolom kayu pilihan yang diambil dari kebun adat melalui ritual adat oleh pemilik $s a^{\prime} O$ dalam hal ini para mosalaki. Di samping itu terdapat wisu mangu. Fungsinya sebagai tiang utama penopang beban atap bangunan. Beban-beban isi hubu/isi rebo (balok bubungan) ditopang langsung oleh mangu.

Ada beberapa pembagian wisu (kolom) antara lain:

1. Kolom yang terdapat pada ruang luar (tenda) memikul balok atas (tenga atas) dan bertumpu pada balok bawah (tenga bawah) pada lantai luar (tenda);

2. Kolom pada bagian dalam atau ruang bagian dalam bangunan (one) memikul balok atas (tenga atas) dan ditopang oleh balok bawah (tenga bawah).

Sistem sambungan yang digunakan pada kolom (wisu) untuk memperkaku konstruksi bangunan adalah sistem sambungan pen (lasu) dan lubang (gemo). Sistem sambungan ini memiliki makna filosofis perkawinan dalam keluarga, yakni pen (lasu) merupakan simbol laki-laki dan lubang (gemo) adalah simbol perempuan. Serta merupakan simbol keutuhan keluarga. Pada sambungan ini tidak diperlukan tali sebagai pengaku sambungan, dikarenakan telah memiliki kekakuan dari setiap batang perangkai (kolom dan balok) oleh gaya tekan (beban) yang bekerja.

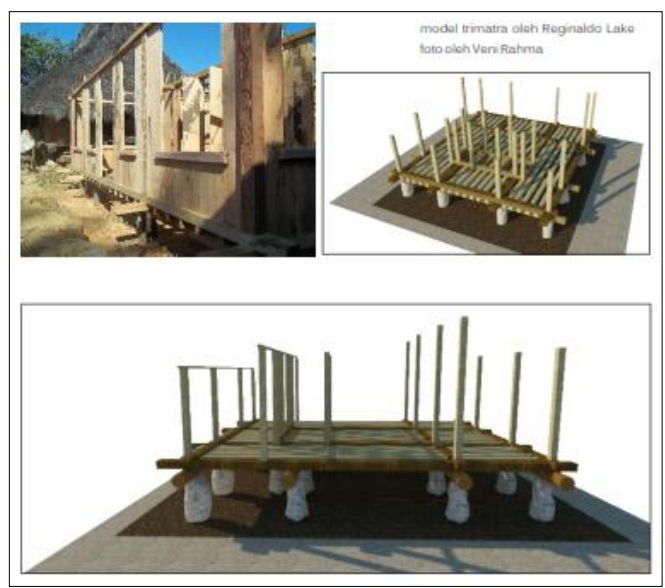

Gambar 5. Posisi meletakkan wisu (tiangtiang kolom)

Sumber: Dokumentasi Pusat Studi Vernakular Unwira, trimatra oleh Egi, 2012
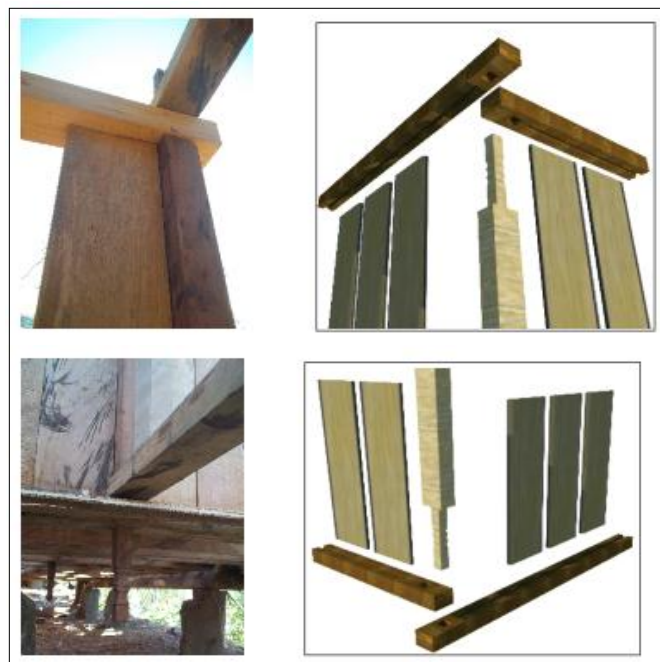

Gambar 6. Sistem sambungan pada wisu (tiang-tiang kolom) dan balok

Sumber: Dokumentasi Pusat Studi Vernakular Unwira, trimatra oleh Egi, 2012 
f. Memasang Dinding Papan dan Beranda

Istilah beranda adalah dinding papan pembatas ruang. Ukuran sebatas lutut. Jenis konstruksi yang digunakan antar tenga bawah dan tenga atas adalah sistem konstruksi jepit.. Sedangkan untuk dinding luar menggunakan papan dengan ukuran tinggi 1.5-2 meter.

Konstruksi dinding sebagai pembatas ruang-ruang ini menggunakan rangka yang diikat pada balok atas dan balok bawah, ujung rangka balok yang timbul sekitar $20 \mathrm{~cm}$ dari balok atas dan balok bawah atau sering disebut lasu dengan sistem sambungan menggunakan pen dan lubang ( $\left.k^{\prime} e b i\right)$. Sedangkan dinding sendiri memiliki dua cara sambungan antara lain:

1. Sambungan dari sisi kiri dan kanan papan memiliki pen atau lubang sekitar 1.5 sampai $3 \mathrm{~cm}$. fungsinya agar papan yang lain disusun secara berurutan;

2. Sambungan dari ujung sisi atas dan bawah papan miring sekitar 3 $\mathrm{cm}$, agar bisa disusun pada balok atas dan balok bawah.

Pemasangan dinding, sekaligus pemasangan pene ria, yaitu pintu utama $s a^{\prime} O$.

Pene ria ini merupakan lambang rahim seorang ibu, sehingga dilengkapi dengan "musu susu ndelo" (payudara seorang ibu) (lambang kesuburan), serta melintang papan di bawah pene ria yakni "koba leke" yang melambangkan perkembangan manusia.

Di samping pene ria (pintu besar) terdapat bendi (senapan) dan relif nipa (ular). Keduanya merupakan simbol pengaman $s a^{\prime} O$.

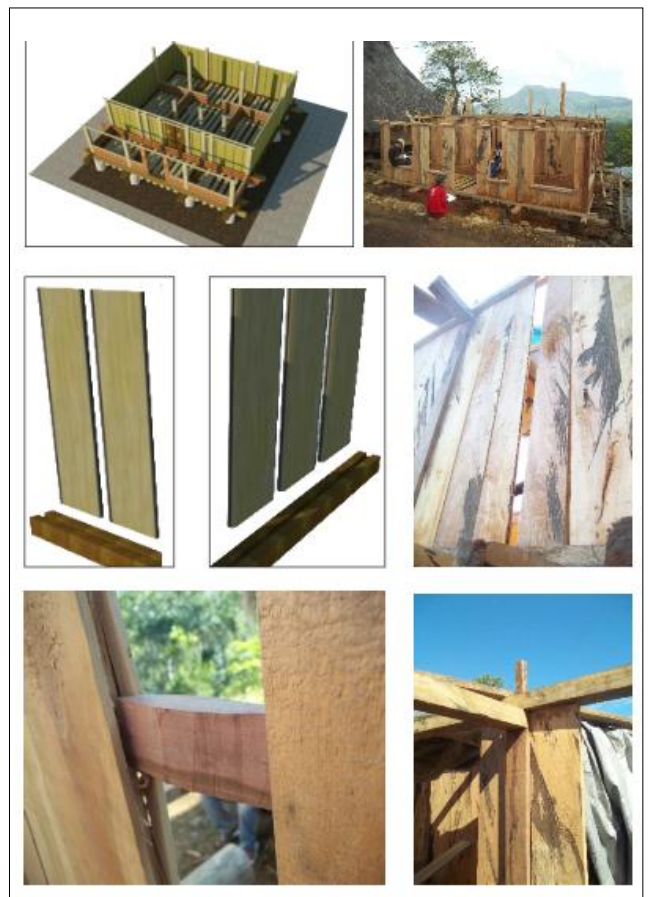

Gambar 7. Memasang dinding papan dan beranda

Sumber: Dokumentasi Pusat Studi Vernakular Unwira, trimatra oleh Egi, 2012

g. Memasang Lantai Papan untuk Lata Papan berukuran 3/30 dengan panjang 5.30 meter menjadi bahan utama lantai dan lata.

Jadi, tahap memasang lantai adalah tahap pembagi ruang $s a$ ' $O$ yang sering disebut tenda (teras/beranda depan difungsikan sebagai ruang menerima tamu, ruang santai dan diperuntukan untuk kaum laki-laki serta tamu), one (ruang tengah adalah ruang yang difungsikan sebagai ruang keluarga, ruang masak yang diperuntukan untuk wanita), waja (tungku masak), lore (selasar), lulu (ruang tidur) dan dhembi (ruang tidur). Pemasangan lantai papan melintang berlawanan dengan balok lantai (gelagar lantai). Terdapat dua bidang lantai pada rumah adat Wologai - Nua pu' $U$ ini, yaitu bidang lantai utama yang terletak dalam bangunan (one) dan bidang lantai bagian luar (tenda). Pada ruang utama (one), lantai dibagi dalam beberapa bagian dengan partisi sebagai pembatas yang sekaligus 
ditempati sebagai tempat tidur dan juga untuk fungsi yang lain seperti ruang menyimpan benda-benda milik suku.

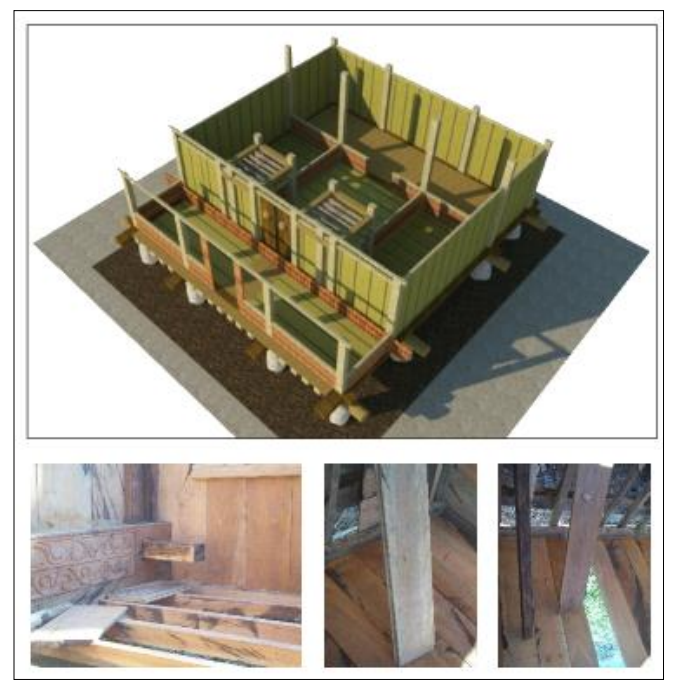

Gambar 8. Memasang lantai papan untuk lata

Sumber: Dokumentasi Pusat Studi Vernakular Unwira, trimatra oleh Egi, 2012

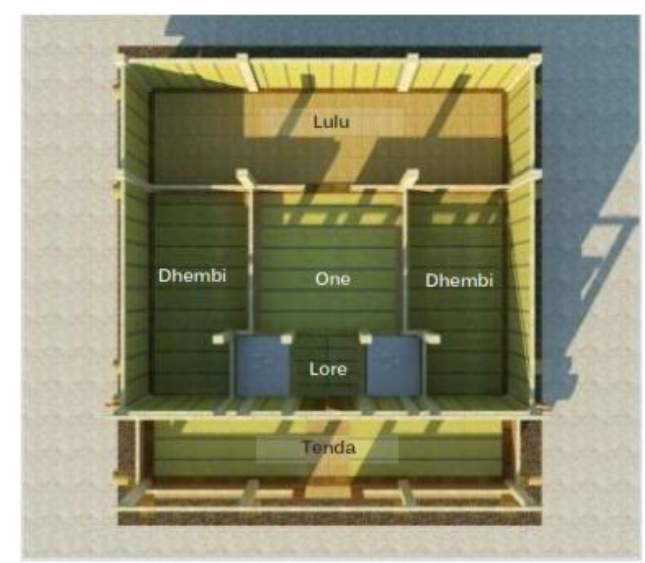

Gambar 9. Denah lantai papan

Sumber: Dokumentasi Pusat Studi Vernakular Unwira, trimatra oleh Egi, 2012

h. Mendirikan Mangu untuk Kogo Laba

Istilah mangu dan kogo laba digunakan untuk menjelaskan bagian paling atas dari kolom lanjutan (wisu). Terdapat 2 (dua) kogo laba untuk menyangga jurai atap dan 2 mangu utama untuk menopang isi hubu atau isi rebo. Sedangkan kogo laba sendiri ditopang oleh ndula dan mede di atas tumpuan wisu.
Pemasangan mangu untuk kogo laba merupakan salah satu pekerjaan yang paling rumit dari proses pembuatan sa' O. Tiga alat bantu digunakan untuk menopang kogo laba dan mangu. Alatalat bantu ini terbuat dari bambu, yakni bambu 1 (satu) berfungsi mendorong mangu dari bawah, sedangkan 2 (dua) bambu menyilang untuk menyangga kogo laba. Setelah selesai dipasang, mangu dan kogo laba diikat menggunakan na'o (tali ijuk) untuk memperkaku struktur mangu dan kogo laba.

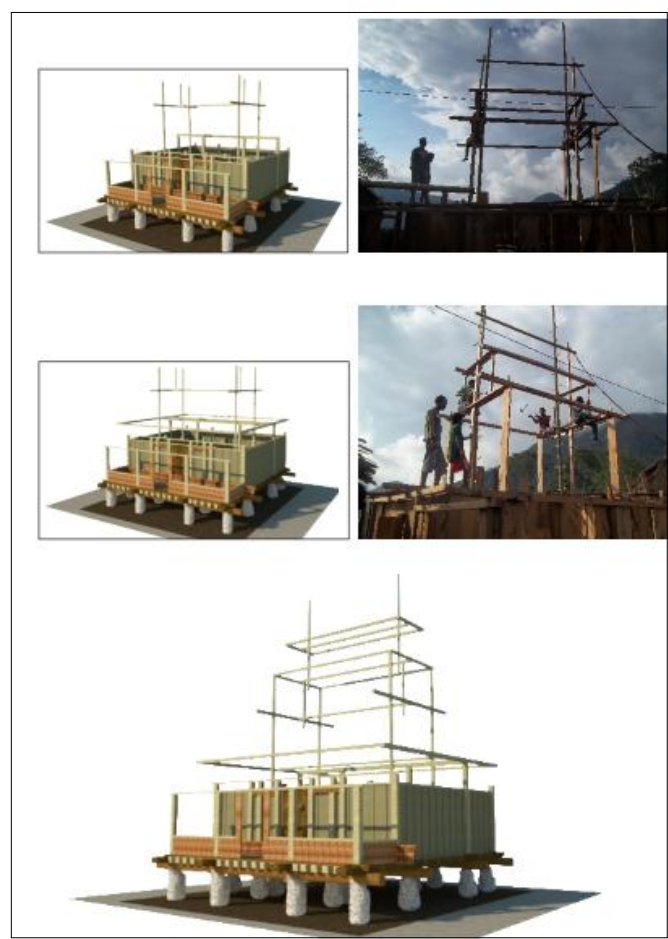

Gambar 10. Mendirikan mangu untuk kogo laba

Sumber: Dokumentasi Pusat Studi Vernakular Unwira, trimatra oleh Egi, 2012

i. Memasang Isi Hubu/isi Rebo

Isi Hubu/Isi Rebo adalah balok yang melintang di bubungan rumah $\left(s a^{\prime} O\right)$. Balok ini melintang dari kiri ke kanan di atas pertengahan ruang tengah. Balok ini harus dipasang oleh saudara laki-laki dari istri mosalaki yang $s a^{\prime} O$ nya mau dibangun. Saudara laki-laki 
ibu dianggap sebagai sumber kehidupan.

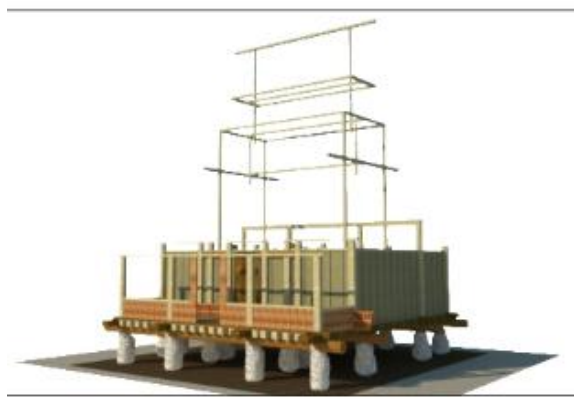

Gambar 11. Memasang isi hubu/isi rebo Sumber: Dokumentasi Pusat Studi Vernakular Unwira, trimatra oleh Egi, 2012

\section{j. Memasang Watu Wula Leja}

Di atas isi hubu, di tengah-tengah berdiri sebuah batu/bambu yang dinamakan watu wula leja sebagai tempat meletakkan persembahan bagi Dua'a Gheta Lulu Wula (penguasa).

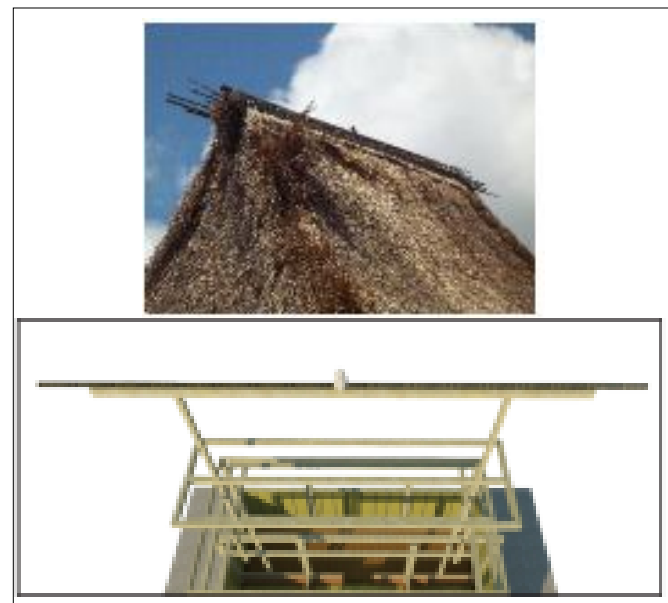

Gambar 12. Memasang watu wula leja Sumber: Dokumentasi Pusat Studi Vernakular Unwira, trimatra oleh Egi, 2012

k. Memasang Olo Theo untuk Pusu Ate Pada balok isi hubu (bubungan) diikat seutas tali yang dinamakan ola theo. Tali ini terbuat dari $n a^{\prime} o$ (tali ijuk) yang digantungkan di tengah-tengh one yang berfungsi menghubungkan "dunia adikodrati" ("dunia super natural") dengan dunia human.
Pada ujung bawah tali diikat sebuah tanduk rusa untuk menggantungkan keranjang kecil yang dinamakan pusu ate untuk menyimpan emping dan beras yang dikeramatkan, dan hanya dipakai pada waktu seremonial pertanian. Oleh karena itu pusu ate juga merupakan lambang kesuburan yang dinamakan hati/perut $s a^{\prime} O$.

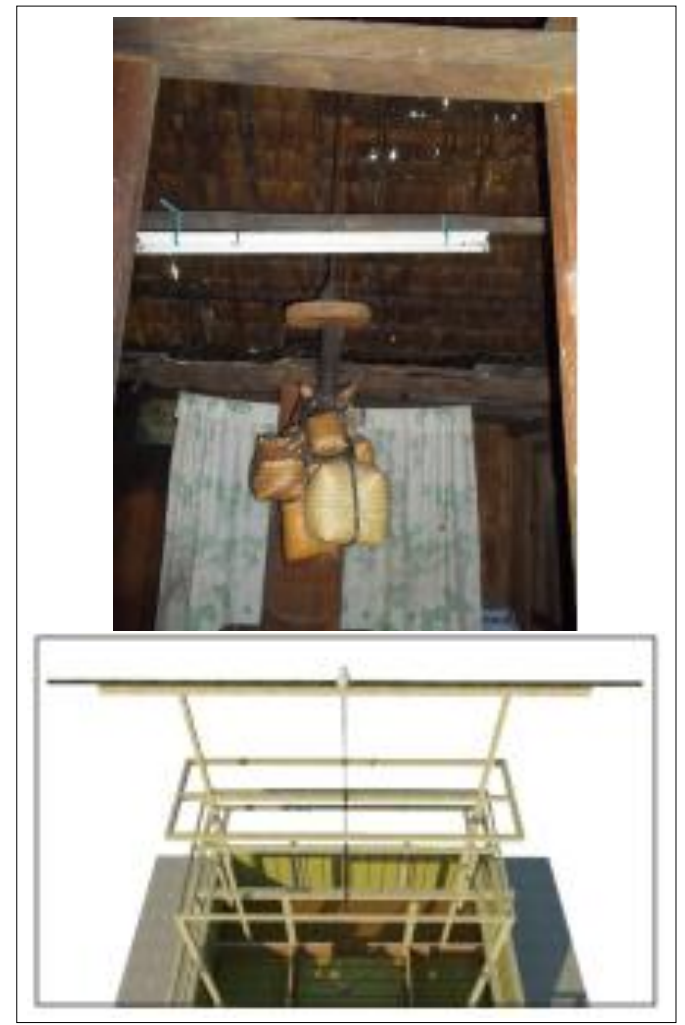

Gambar 13. Memasang olo theo untuk pusu ate

Sumber: Dokumentasi Pusat Studi Vernakular Unwira, trimatra oleh Egi, 2012

\section{Memasang Jurai Ate}

Jurai ate terbuat dari bambu utuh. Jurai ate ini merupakan rangka terluar untuk mengikat atap ijuk dan alangalang. Jumlah jurai utama (jurai luar) adalah 4 (empat) dan disusul jurai-jurai pendukung/jurai dalam (berfungsi sebagai gording dan reng) yang jumlahnya tidak dipastikan. Jarak antar jurai, gording dan reng tidak dihitung terukur, tapi menggunakan perkiraan saja. Perkuatan jurai, gording dan reng 
ate ini menggunakan konstruksi ikat sulam dari $n a^{\prime} o$ (tali ijuk).

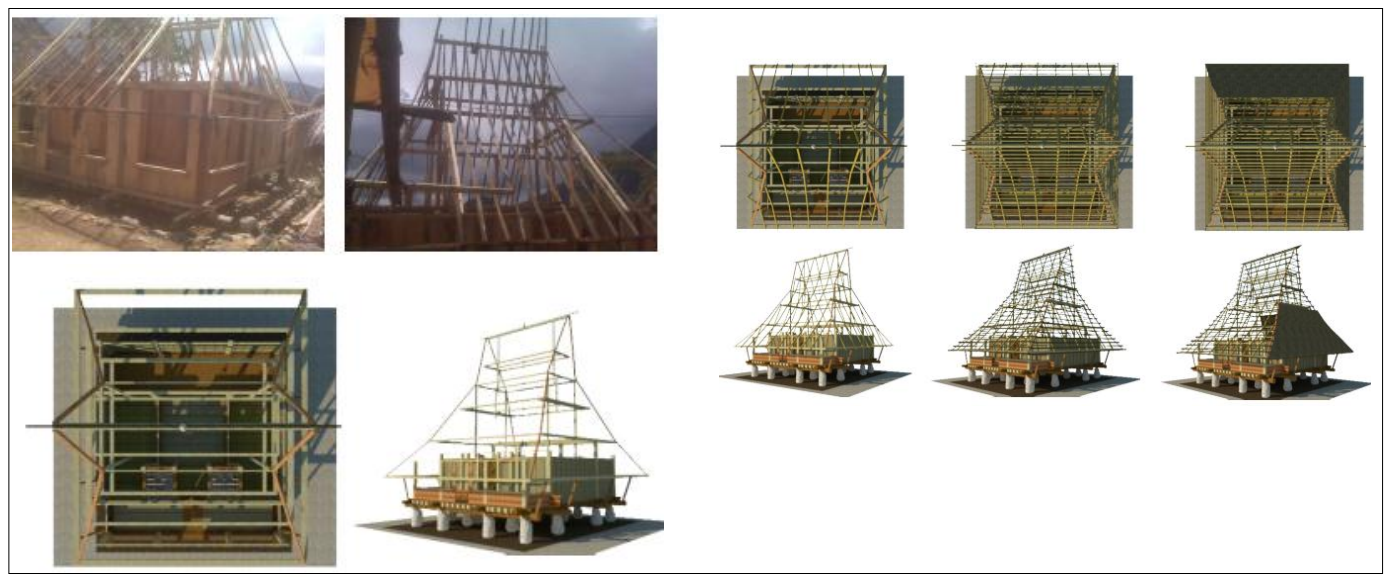

Gambar 14. Memasang jurai ate

Sumber: Dokumentasi Pusat Studi Vernakular Unwira, trimatra oleh Egi, 2012

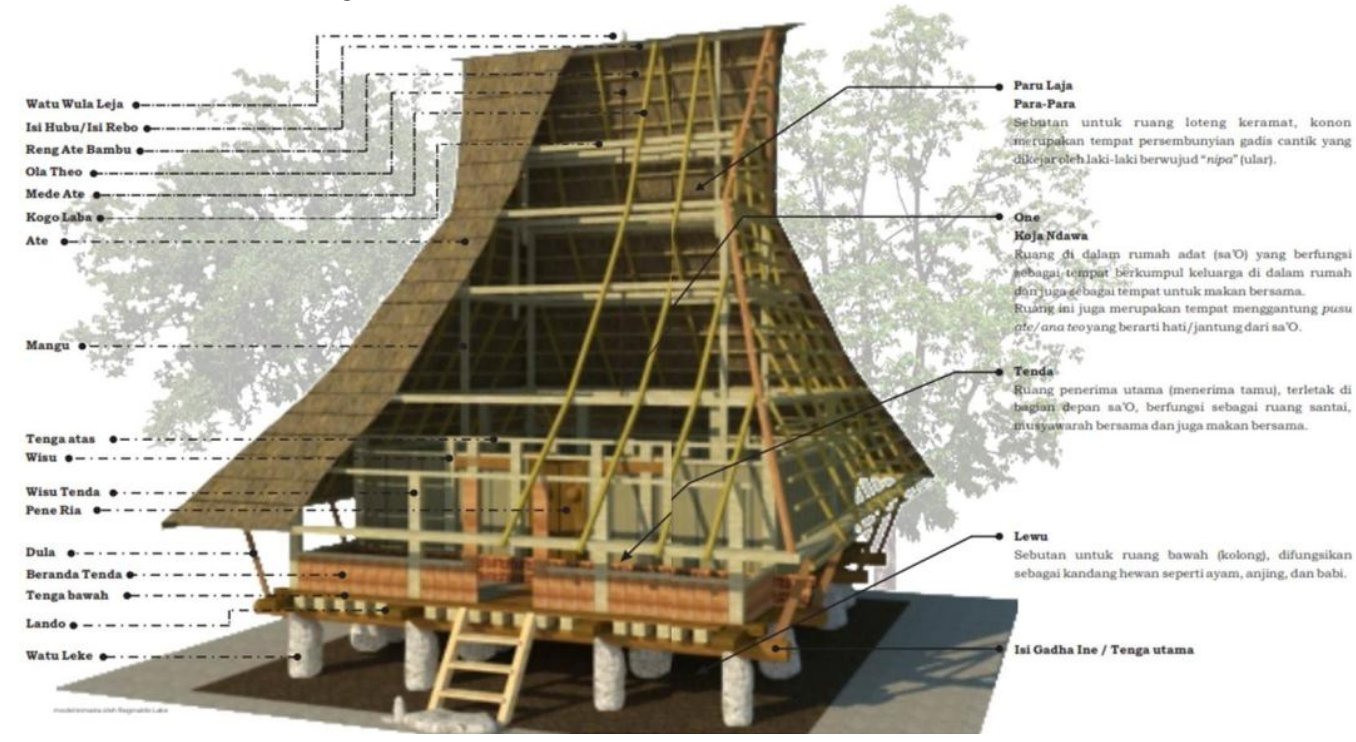

Gambar 15. Potongan massa bangunan $\mathrm{Sa}^{\prime} \mathrm{O}$

Sumber: Dokumentasi Pusat Studi Vernakular Unwira, trimatra oleh Egi, 2012

Keterangan gambar 15:

\section{Paru Laja}

\section{Para-para}

Sebutan untuk ruang loteng keramat, konon merupakan tempat persembunyian gadis cantik yang dikejar oleh laki-laki berwujud "nipa" (ular).

\section{One}

\section{Koja Ndawa}

Ruang di dalam rumah adat ( $\left(a^{\prime} O\right)$ yang berfungsi sebagai tempat berkumpul keluarga di dalam rumah dan juga sebagai tempat untuk makan bersama. Ruang ini juga merupakan tempat menggantung pusu ate/ana teo yang berarti hati/jantung sari sa'O.

\section{Tenda}

Ruang penerima utama (menerima tamu), terletak di bagian depan $s a^{\prime} O$, berfungsi sebagai ruang santai, musyawarah bersama dan juga makan bersama. 
m. Memasang Tangga Depan

Tangga untuk memasuki rumah $\left(s a^{\prime} O\right)$ terdiri dari 3 anak tangga. Dua anak tangga (teratas) terbuat dari papan dan satu anak tangga terbuat dari batu plat (watu plat) (terbawah).

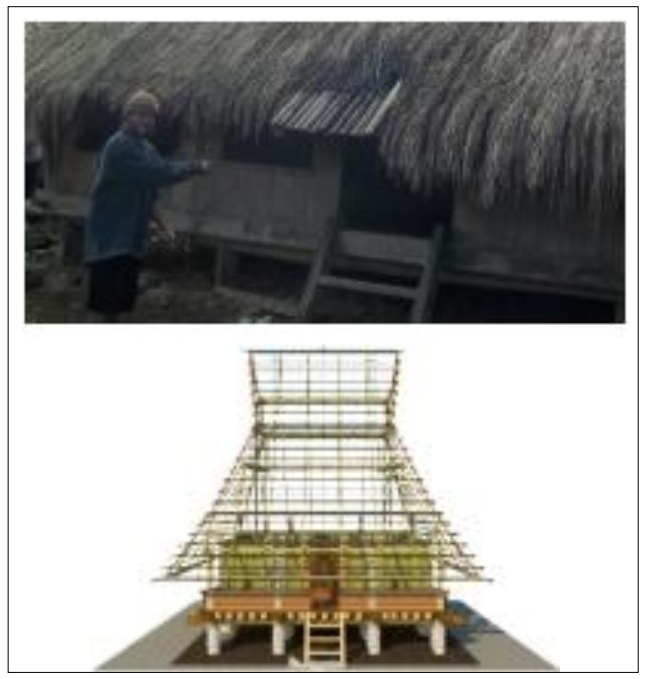

Gambar 16. Memasang tangga depan

Sumber: Dokumentasi Pusat Studi Vernakular Unwira, trimatra oleh Egi, 2012

n. Memasang Ate

Atap sa' $O$ dinamakan ate.

Ate terbuat dari eba (alang-alang) dan atau $n a^{\prime} o$ (ijuk) yang membentang dari bubungan hingga ke pertemuan dinding-dinding dan lantai $s a^{\prime} O$. Ate membatasi ruang secara vertikal dan horisontal. Ia membatasi "alam terang" dan "alam gelap".

Alang-alang atau ijuk sebagai bahan utamanya diikat terlebih dahulu membentuk satuan alang-alang/ijuk memakai tali $n a^{\prime} o$ dan diikat pada bambu-bambu reng.

Tata/susunan ate dimulai dari bawah hingga isi hubu. Untuk bagian bawah digunakan dua lapisan alang-alang/ijuk kemudian diikuti ke baris berikutnya satu lapisan dan seterusnya.

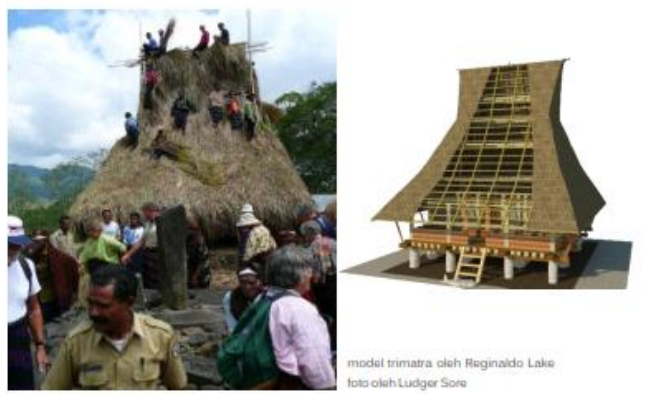

Gambar 17. Memasang ate

Sumber: Dokumentasi Pusat Studi Vernakular Unwira, trimatra oleh Egi, 2012

o. Upacara Pembersihan Rumah ( $\mathrm{Sa}$ ' O)

Setelah proses pembangunan $s a^{\prime} O$ selesai hingga pemasangan ate, maka dilanjutkan dengan ritual adat pembersihan $s a^{\prime} O$. Umumnya upacara yang diselenggarakan berupa upacara membakar pisang. Maksudnya adalah untuk memasuki $s a^{\prime} O$ baru (harus) dalam keadaan bersih. Selain itu ayam (manu) dan babi (wawi) pun dibakar untuk memohon berkat dari Dua gheta lulu wula dan nenek-moyang atas rumah dan penghuninya.

\section{Kesimpulan}

Budaya tektonika Wologai terkait pada aturan-aturan/norma-norma yang berlaku dalam adat istiadat masyarakat. Hal ini terlihat sangat jelas dari proses pembangunan $s a$ ' $O$ yang dikerjakan tahap demi tahap. Selain itu budaya tektonika Wologai dipengaruhi oleh sistem struktur sosial, dalam hal ini para pelaku (architecton) yang terlibat di dalam proses pembangunan.

Hal yang paling utama dalam budaya tektonika Wologai adalah tradisi ritual adat. Tiap ritual adat yang dilaksanakan merupakan wujud permohonan berkat bagi proses pembangunan tersebut dan permintaan berkat kemakmuran serta 
kesejahteraan bagi seluruh rakyat Wologai.

Material yang digunakan dalam bangunan $s a^{\prime} O$ adalah alang-alang, bambu, kayu, dan ijuk. Material yang dikumpulkan masyarakat berasal dari lingkungan sekitarnya dan didahului oleh upacara adat meminta ijin pada alam sebagai wujud penghargaan kepada lingkungan hidup. Pengolahan dari bahan-mentah menjadi bahan bangunan-matang (siap-pakai), serta jenis konstruksi yang digunakan masih sangat sederhana, yakni menggunakan teknik bersahaja sesuai keadaan alam dan iklim permukiman.

\section{Daftar Pustaka}

Abel, C. (1996). Architecture and identity: Toward a global ecoculture.

Cambridge: Architecture Press, pp. 145-147

Alfan, M. (2013). Filsafat kebudayaan. Bandung: Pustaka Setia.

Frampton, K. (1995). Studies on tectonic culture. Cambridge, MA: MIT Press

Lake, R.. (2015). Wologai, eksotisme vernakular di kaki Gunung Lepembusu. Kupang: Yayasan Gita Kasih.

Norberg-Schulz, C. (1985). The concept of dwelling. New York: Rizzoli.

Norberg-Schulz, C. (1988). Architecture, meaning and place. New York: Rizzoli.

Oliver, P. (1975). Shelter, sign \& symbol. London: Highbury Crescent.

Oliver, P. (2003). Dwellings: The vernacular house world wide. London and New York: Phaidon Press.

Ping-Gao, W. (1999). Tectonics? A case study for digital free-form architecture, paper works.

Hsinchu: Institute of

Architecture National ChiaoTung University.

Salura, P. (2001). Ber-arsitektur, membuat, menggunakan, mengalami dan memahami arsitektur. Bandung: Architecture \& Communication.

Salura, P. (2008). Colours of culture in architecture. Bandung: Cipta Sastra Salura. 